\title{
Theory of Reasoned Action sebagai Prediktor Whistleblowing Intention Pengelola Keuangan di Institusi Pendidikan
}

\author{
I Wayan Yeremia Natawibawa ${ }^{\mathrm{a}} *$, Gugus Irianto ${ }^{\mathrm{b}}$, Roekhudin ${ }^{\mathrm{c}}$ \\ ${ }^{a b c}$ Universitas Brawijaya, Malang, Jawa Timur, Indonesia
}

\section{INFORMASI ARTIKEL}

\section{Article history:}

Dikirim tanggal: 28 September 2018

Revisi pertama tanggal: 03 Oktober 2018

Diterima tanggal: 07 Desember 2018

Tersedia online tanggal: 31 Desember 2018

Keywords: Theory of Reasoned Action, perception, whistleblowing

\section{ABSTRACT}

This research was aimed to analyze the perception of financial keepers in school organization on whistleblowing intention and to understand this relationship through Theory of Reasoned Action (TRA). Population of research was 214 persons comprising of 24 principals, 97 vice-principals, 22 school administration heads, 32 treasurers, and 39 financial administration staffs in Public Senior/ Vocational/ Moslem High Schools in Malang City. Census sampling technique was used. Data were collected with questionnaire. There are 192 questionnaires were returned and were completely filled. Multiple regression analysis instrument was used in this research. Result of research indicated that attitude toward whistleblowing and subjective norm are positively affect whistleblowing intention.

\section{INTISARI}

Penelitian ini menganalisis persepsi pengelola keuangan dalam lembaga sekolah terhadap tindakan whistleblowing yang berlandaskan pada Theory of Reasoned Action (TRA). Populasi berjumlah 214 orang yang terdiri dari 24 orang kepala sekolah, 97 orang wakil kepala sekolah, 22 orang kepala tata usaha, 32 orang bendahara, dan 39 orang pegawai administrasi keuangan di SMA/ SMK/ MA Negeri se - Kota Malang. Penelitian ini menggunakan teknik sampling sensus. Pengumpulan data mengunakan kuesioner. Kuesioner yang kembali dan terisi dengan lengkap adalah sebanyak 192 buah. Teknik analisis regresi berganda digunakan dalam penelitian ini. Hasil penelitian menunjukkan bahwa sikap terhadap whistleblowing dan norma subyektif berpengaruh positif terhadap whistleblowing intention.

\section{Pendahuluan}

Korupsi dan berbagai bentuk fraud lainnya dapat terjadi diberbagai sektor, termasuk juga disektor pendidikan. Pendidikan adalah hak asasi manusia yang fundamental dan merupakan pendorong utama perkembangan manusia dan perekonomian. Sektor ini sangat rentan terhadap korupsi, mulai dari kementerian pendidikan nasional hingga sekolah setempat karena sektor pendidikan biasanya terdiri dari $20 \%$ hingga $30 \%$ anggaran negara (Transparency International, 2017). Semakin besar jumlah anggaran pendidikan, maka potensi korupsi yang dapat terjadi juga akan semakin besar (Handayani, 2009). Kerugian akibat kasus korupsi

* Corresponding author. Tel.: +62-813-5741-7189; e-mail: jerry_bali@yahoo.co.id 
dilembaga sekolah dalam rentang waktu 2005 sampai dengan 2016 adalah mencapai 136 miliar rupiah yang mana terdapat 65 orang kepala sekolah dan 27 orang bendahara sekolah menjadi tersangka korupsi (Susanti, 2018). LPPKS Kemdikbud Indonesia mengungkapkan bahwa terdapat tiga bentuk masalah yang sering muncul dalam pengelolaan keuangan lembaga sekolah, yaitu penyalahgunaan keuangan lembaga sekolah untuk memperkaya diri atau yang disebut dengan korupsi, pelaporan keuangan lembaga sekolah yang seringkali terdapat manipulasi, dan penyimpangan dalam pembelanjaan keuangan, misalnya penyimpangan anggaran pengadaan buku yang dilakukan oleh manager sekolah (LPPKS, 2013:20).

Yang menjadi permasalahan adalah mengungkap kasus pelanggaran yang terjadi dalam lembaga sekolah tidak mudah. Koordinator Satgas Masyarakat Antimafia, Tri Suharjanto, menyatakan bahwa meskipun dugaan kasus korupsi di lingkungan pendidikan sering terjadi, namun sebagian besar orang mendiamkan hal tersebut, termasuk juga para guru. Yang menjadi salah satu penyebab mereka enggan melaporkan dugaan korupsi di sektor pendidikan adalah karena mereka takut tertimpa akibat buruk, misalnya hambatan karir (Ramadhan, 2016).

Dalam upaya memerangi praktik korupsi di dunia pendidikan, Kementerian Pendidikan dan Kebudayaan menandatangani nota kesepahaman dengan KPK pada tanggal 4 Agustus 2017. Salah satu nota kesepahaman itu adalah pelayanan pengaduan masyarakat atau whistleblowing system diKemdikbud pada kanal Posko Pengaduan Inspektorat Jenderal melalui laman pengaduan.itjen.kemdikbud.go.id (Antara, 2017). Keberhasilan atau kegagalan penerapan suatu sistem teknologi informasi adalah bergantung pada manusianya yang mau atau tidak mau untuk menggunakannya dengan banyak alasan (Jogiyanto, 2007:2). Whistleblowing dapat diartikan sebagai pengungkapan yang dilakukan oleh anggota organisasi mengenai praktik ilegal yang berada di dalam kendali atasan mereka kepada orang yang mungkin dapat mengambil tindakan (Mustapha dan Ling Ling, 2012).

Whistleblowing merupakan salah satu mekanisme pengendalian internal untuk mencegah pelanggaran organisasi dan oleh karena itu penting untuk mendorong mereka yang memiliki pengetahuan luas untuk tampil mengungkapkan informasi ini (Zakaria, 2015). Whistleblowing diklaim sebagai alat yang penting untuk mengurangi korupsi dan situasi yang berbahaya karena whistleblowing dapat meningkatkan pengungkapan informasi tentang kegiatan ilegal, berbahaya, atau tidak etis oleh pemerintah dan organisasi swasta (Mustapha dan Ling Ling, 2012). Crook (2000) menyatakan bahwa $75 \%$ dari keseluruhan fraud yang ditemukan secara kebetulan, salah satunya adalah melalui whistleblowing. Winardi (2013) mengungkapkan bahwa di dalam pemerintahan, pegawai negeri tingkat rendah seperti karyawan merupakan whistleblower yang potensial karena mereka terlibat aktif dalam kegiatan operasional dan teknis organisasi. Karyawan memiliki pengetahuan yang terperinci tentang bagaimana organisasi mereka bekerja dan mereka adalah orang - orang yang paling mungkin mengetahui tentang adanya korupsi di tempat mereka bekerja.

Meskipun whistleblowing merupakan salah satu alat yang efektif dalam mengungkap fraud, namun yang menjadi persoalan adalah whistleblowing merupakan perbuatan yang akan menimbulkan dilema (Waytz, dkk., 2013). Whistleblowing mendukung kejujuran, namun disisi yang lain juga tampak tidak loyal sehingga whistleblowing seringkali merupakan konflik moral (Waytz, dkk., 2013). Dalam bisnis, whistleblowing sering dikecam karena tidak dapat dibenarkan secara moral dengan alasan melanggar kewajiban loyalitas dan kerahasiaan bisnis serta rekan kerja (Crook, 2000). Oleh karena itu, karyawan mungkin menyadari bahwa ada sesuatu pelanggaran dalam organisasi mereka, tetapi seringkali mereka tidak mengungkapkan keprihatinan mereka. Mungkin mereka merasa bahwa mengungkap pelanggaran dalam organisasi dianggap sebagai perbuatan yang tidak setia kepada rekan kerja atau organisasi atau mereka merasa takut akan menjadi korban (Crook, 2000).

Oleh karena whistleblowing merupakan suatu bentuk tindakan yang seringkali memunculkan dilema, maka penting bagi suatu organisasi untuk mempelajari berbagai faktor yang dapat mempengaruhi niat anggota organisasi untuk melaksanakan tindakan whistleblowing sehingga kebijakan dan sistem whistleblowing organisasi yang dirancang dapat berfungsi secara efektif (Bagustianto \& Nurkholis, 2014). Niat seseorang untuk melakukan whistleblowing dapat dijelaskan oleh teori keperilakuan. Pada Tahun 1980, Icek Ajzen dan Martin Fishbein membangun teori keperilakuan yang dikenal dengan Teori Tindakan Beralasan (Theory of Reasoned Action - TRA). TRA menjelaskan bahwa terwujudnya perilaku disebabkan oleh adanya minat individual atau yang disebut juga dengan keinginan individual untuk mewujudkan perilaku. Perilaku merupakan tindakan nyata. Menurut TRA, minat untuk melakukan perilaku tersebut ditentukan oleh dua konstruk, yaitu konstruk sikap terhadap perilaku (attitude toward behavior) dan konstruk norma subyektif (subjective norm).

Beberapa peneliti telah melakukan penelitian minat untuk melakukan tindakan whistleblowing yang mengacu pada konstruk TRA. Akan tetapi, penelitian yang mereka lakukan masih menunjukkan hasil yang belum konsisten. Dalam penelitian whistleblowing, 
beberapa peneliti berhasil membuktikan bahwa kedua konstruk yang terdapat dalam TRA, yaitu sikap dan norma subyektif mampu memprediksi minat untuk melakukan whistleblowing. Akan tetapi, terdapat pula beberapa penelitian yang tidak berhasil membuktikan adanya pengaruh sikap dan norma terhadap minat untuk melakukan whistleblowing sehingga TRA tidak dapat dijadikan sebagai prediktor minat untuk melakukan tindakan whistleblowing. Oleh karena itu, penelitian ini bertujuan untuk menguji kembali kedua konstruk yang terdapat dalam TRA, yaitu sikap dan norma subyektif terhadap minat untuk melakukan whistleblowing (whistleblowing intention) pada SMA/ MA/ SMK Negeri se - Kota Malang.

\section{Teori}

\subsection{Administrasi Keuangan Lembaga Pendidikan Sekolah}

Keuangan maupun pembiayaan adalah sumber daya yang mendukung secara langsung efektivitas serta efisiensi dalam pengelolaan institusi pendidikan. Keuangan serta pembiayaan adalah potensi yang menentukan dan merupakan suatu bagian yang tercakup pada kajian manajemen pendidikan. Komponen keuangan maupun pembiayaan dalam institusi sekolah adalah suatu komponen produksi yang dapat menentukan terwujudnya kegiatan proses belajar mengajar pada institusi sekolah bersama dengan berbagai komponen lainnya. Dapat diartikan bahwa secara disadari maupun tidak disadari, setiap kegiatan yang dilaksanakan oleh lembaga sekolah memerlukan biaya. Komponen keuangan serta pembiayaan ini penting untuk dikelola dengan baik supaya dana yang tersedia dapat digunakan secara optimal guna mendukung terwujudnya tujuan dari pendidikan (Mulyasa, 2009:48).

\subsection{Pengelola Keuangan Lembaga Sekolah}

Pengelola keuangan sekolah meliputi kepala sekolah, wakil kepala sekolah, kepala tata usaha, dan bendahara sekolah (Windarti, 2015). Dalam kegiatan manajemen keuangan sekolah berpatokan pada azas pemisahan tugas diantara fungsi yang terdiri dari otorisator, ordonator, dan bendahara (Mulyasa, 2009:49). Otorisator merupakan pejabat yang memiliki wewenang untuk melakukan tindakan yang berakibat pada penerimaan dan pengeluaran anggaran. Ordonator merupakan pejabat yang memiliki wewenang menguji dan memerintahkan pembayaran atas tindakan yang dilakukan sesuai dengan otoritas yang sudah ditetapkan (Mulyasa, 2009:49). Kepala sekolah berperan dalam pengawasan keuangan sekolah, otorisator, dan juga memiliki fungsi sebagai ordonator untuk memerintahkan pembayaran. Akan tetapi, jabatan kepala sekola tidak dibenarkan unuk melaksanakan fungsi sebaai bendaharawan karena kepala sekolah memiliki kewajiban melakukan pengawasan ke dalam (Mulyasa, 2009:49). Selanjutnya, salah satu tugas kepala tata usaha (TU) berdasarkan pada Keputusan Dirjen Dikdasmen No. 260 dan 261 Tahun 1996 adalah bertanggung jawab dalam pengelolaan keuangan lembaga sekolah. Bendaharawan merupakan pejabat yang memiliki wewenang untuk melakukan penerimaan, penyimpanan, serta pengeluaran uang maupun berbagai surat berharga yang dapat dinilai dengan uang dan juga memiliki kewajiban dalam membuat perhitungan dan pertanggungjawaban (Mulyasa, 2009:49). Menurut LPPKS, tugas pokok bendaharawan adalah melakukan berbagai bentuk administrasi keuangan dalam lembaga sekolah yang antara lain keuangan rutin/ UYHD/ BOPS, dana BOS, dana komite sekolah, dan juga berbagai dana dari sumber lainnya. Selain itu, bendaharawan juga bertanggung jawab secara langsung kepada kepala TU. Bendahara sekolah selain memiliki fungsi bendaharawan, mereka juga bertangung jawab atas fungsi sebagai ordonator yaitu menguji hak atas pembayaran (Mulyasa, 2009:49). Dalam lingkup organisasi sekolah yang besar, bendahara sekolah dapat dibantu oleh beberapa orang pegawai administrasi keuangan agar pelaksanaan pengelolaan keuangan lembaga sekolah dapat berfungsi dengan efektif.

\subsection{Fraud}

The Association of Certified Fraud Examiners (ACFE) mendefinisikan fraud dan penyalahgunaan wewenang sebagai penggunaan jabatan seseorang untuk keuntungan pribadi melalui penyalahgunaan atau pencurian sumber daya atau aset organisasi. ACFE mendefinisikan fraud laporan keuangan sebagai penyimpangan pada kondisi keuangan yang disengaja pada sebuah perusahaan atau organisasi yang dilakukan melalui bentuk salah saji secara sengaja maupun penghilangan dari jumlah ataupun pengungkapan pada laporan keuangan yang bertujuan untuk menipu para pengguna laporan keuangan.

\subsection{Whistleblowing}

Komite Nasional Kebijakan Governance (KNKG) mendefinisikan pengungkapan kecurangan (whistleblowing) sebagai pengungkapan tindakan pelanggaran atau pengungkapan perbuatan yang melawan hukum, perbuatan tidak etis/ tidak bermoral atau perbuatan lain yang dapat merugikan organisasi maupun pemangku kepentingan, yang dilakukan oleh karyawan maupun pimpinan organisasi terhadap pimpinan organisasi maupun lembaga lain yang memiliki wewenang untuk mengambil tindakan 
terhadap pelanggaran tersebut. Secara umum, pengungkapan dilakukan secara rahasia (confidential).

Selanjutnya KNKG menyatakan bahwa pengungkapan harus dilakukan dengan dilandaskan pada itikad baik dan bukan keluhan pribadi terhadap suatu kebijakan (grievance) atau juga berdasarkan atas kehendak buruk/ fitnah. KNKG lebih lanjut menerangkan bahwa whistleblower merupakan karyawan organisasi atau pihak internal, namun dapat pula pelapor adalah pihak eksternal antara lain pelanggan, pemasok, maupun masyarakat. Whistleblower sebaiknya memberikan bukti, informasi, maupun indikasi yang jelas mengenai laporan pelanggaran, sehingga laporan tersebut dapat untuk ditelusuri dan ditindaklanjuti. Tanpa disertai dengan informasi yang memadai, maka laporan akan sulit untuk ditindaklanjuti.

\subsection{Teori Tindakan Beralasan (Theory of Reasoned Action)}

Teori tindakan beralasan (Theory of Reasoned Action - TRA) dibangun oleh Icek Ajzen dan Martin Fishbein di Tahun 1980. Dalam Teori Tindakan Beralasan; minat perilaku serta perilaku merupakan dua hal yang tidak sama. Minat atau niat merupakan keinginan melakukan suatu perilaku sedangkan perilaku adalah tindakan sesungguhnya atau nyata yang dilakukan individu. TRA menjelaskan bahwa keinginan untuk melakukan perilaku tersebut ditentukan oleh adanya konstruk sikap terhadap perilaku (attitude toward behavior) dan konstruk norma subyektif (subjective norm). Sikap diartikan sebagai perasaan positif atau negatif pada diri seseorang dalam melakukan suatu tindakan nyata sementara norma subyektif merupakan persepsi dari seseorang tentang berbagai kepercayaan orang lain yang berpengaruh terhadap niat orang tersebut untuk melakukan maupun tidak melakukan perilaku yang sedang dipertimbangkannya (Jogiyanto, 2007:35).

Dengan demikian, ada tiga tahapan manusia untuk melakukan perilaku, yang dijelaskan oleh TRA, yaitu (Jogiyanto, 2007:35):

a) Pada awalnya, perilaku akan ditentukan oleh niat atau minat;

b) Pada tahap kedua, minat tersebut dapat dijelaskan melalui bentuk sikap terhadap perilaku (attitudes toward the behavior) dan norma - norma subyektif (subjective norm); dan

c) Tahap ketiga adalah individu mempertimbangkan berbagai sikap (attitudes) dan norma subyektif (subjective norm) melalui berbagai kepercayaan mengenai konsekuensi untuk melakukan perilakunya dan mengenai harapan normatif dari orang yang direferensi (referent) yang relevan.
Gambar 1 dibawah menunjukkan model Teori Tindakan Beralasan yang dibangun oleh Icek Ajzen dan Martin Fishbein pada Tahun 1980.

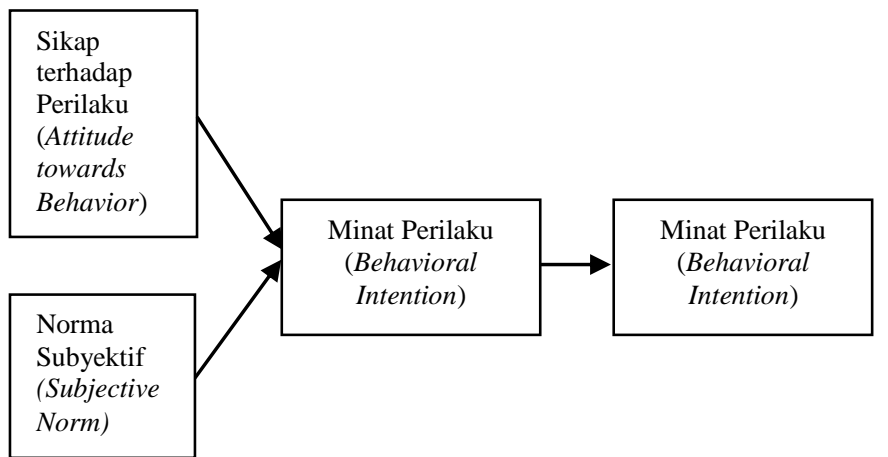

Gambar 1 Model Teori Tindakan Beralasan Sumber: Jogiyanto (2007:33)

\subsection{Pengaruh Sikap Terhadap Whistleblowing Intention}

Sikap mengacu pada sejauh mana seseorang atau individu memberikan evaluasi atau penilaian yang baik ataupun tidak baik terhadap perilaku yang bersangkutan (Ajzen, 1991). Sikap dapat pula dirtikan sebagai pandangan positif atau negatif maupun pandangan menguntungkan atau tidak menguntungkan seseorang terhadap suatu perilaku. Semakin baik atau positif pandangan seseorang terhadap suatu perilaku, maka akan bertambah besar niat seseorang dalam melakukan perilaku tersebut. Sebagai aturan umum, semakin baik sikap terhadap perilaku, maka akan bertambah kuat pula keinginan atau niat seseorang untuk mewujudkan perilaku tersebut (Ajzen, 1991).

Beberapa peneliti yang menguji pengaruh sikap terhadap minat untuk melakukan whistleblowing antara lain Zakaria, dkk. (2016), Suryono dan Chariri (2016), Winardi (2013), Aliyah (2015), Khairunnisa (2017), Bagustianto dan Nurkholis (2014), Rustiarini dan Sunarsih (2017), Siallagan, dkk. (2017), Ponnu, dkk. (2008), Sharif (2015), Parianti, dkk. (2016), Wei, dkk., (2016), Poespito (2017), serta Park dan Blenkinsopp (2009). Penelitian yang dilakukan oleh Zakaria, dkk. (2016), Winardi (2013), Khairunnisa (2017), Bagustianto dan Nurkholis (2014), Siallagan, dkk. (2017), Ponnu, dkk. (2008), Sharif (2015), Parianta, dkk. (2016), serta Wei, dkk. (2016) membuktikan bahwa sikap memiliki pengaruh terhadap niat untuk melakukan whistleblowing. Akan tetapi, penelitian Suryono dan Chariri (2016), Aliyah (2015), Poespito (2017), serta Rustiarini dan Sunarsih (2017) membuktikan bahwa sikap tidak berpengaruh terhadap minat untuk melakukan whistleblowing. Untuk di Indonesia, beberapa argumen yang mendasari adalah whistleblowing belum sepenuhnya dipahami dan 
diapresiasi oleh pemerintah Indonesia, bahkan masyarakat di Indonesia menganggap bahwa whistleblower sebagai orang yang mencoba menjadi pahlawan atau orang yang mencari popularitas (Rustiarini dan Sunarsih, 2017). Park dan Blenkinsopp (2009) yang meneliti pengaruh sikap terhadap minat untuk melakukan whistleblowing internal dan eksternal dari 296 anggota kepolisian di Korea juga menemukan bahwa sikap hanya mempengaruhi minat untuk melakukan whistleblowing internal saja. Park dan Blenkinsopp (2009) berargumen bahwa whistleblowing secara internal memiliki dua manfaat, yaitu untuk memperbaiki manajemen risiko dan yang kedua whistleblowing eksternal umumnya akan dipandang oleh organisasi akan memiliki konsekuensi negatif terhadap reputasi organisasi. Berdasarkan pada uraian tersebut, maka peneliti menyusun hipotesis alternatif sebagai berikut:

H1 : Sikap berpengaruh positif terhadap whistleblowing intention.

\subsection{Pengaruh Norma Subyektif terhadap Whistleblowing Intention}

Norma subyektif adalah pengaruh sosial yang berupa kepercayaan orang lain yang memiliki pengaruh terhadap seseorang untuk melakukan atau tidak melakukan suatu bentuk perilaku (Ajzen, 1991). Norma subyektif dapat berarti persepsi atau pandangan banyak orang mengenai perilaku apa yang seharusnya dilakukan dan perilaku apa yang seharusnya tidak dilakukan. Ketika banyak orang memandang perilaku tertentu itu baik dan seharusnya dilakukan, maka pandangan orang banyak tersebut akan mempengaruhi minat seseorang untuk melakukan perilaku tersebut. Whistleblowing merupakan salah satu mekanisme pengendalian internal organisasi untuk melaporkan adanya pelanggaran atau penyimpangan yang ada di dalam organisasi kepada pihak yang dapat mengatasi pelanggaran atau penimpangan tersebut agar organisasi dapat mencapai tujuannya. Oleh karena itu, semakin tinggi norma subyektif, maka akan dapat mempengaruhi minat seseorang untuk melakukan whistleblowing.

Beberapa peneliti yang menguji pengaruh norma subyektif terhadap minat untuk melakukan whistleblowing antara lain Zakaria, dkk (2016), Winardi (2013), Khairunnisa (2017), Rustiarini dan Sunarsih (2017), Siallagan (2017), Ponnu dkk (2008), Parianti, dkk (2016), Wei, dkk (2016), Sharif (2015), Suryono dan Chariri (2016), Poespito (2017), serta Park dan Blenkinsopp (2009). Penelitian yang dilakukan oleh Winardi (2013), Khairunnisa (2017), Siallagan (2017), Parianti, dkk. (2016), Wei, dkk (2016), Sharif (2015), Suryono dan Chariri (2016), serta Park dan Blenkinsopp
(2009); membuktikan bahwa norma subyektif memiliki pengaruh terhadap niat untuk melakukan whistleblowing. Zakaria, dkk (2016) yang meneliti pengaruh norma subyektif terhadap minat untuk melakukan whistleblowing internal dan eksternal dengan menggunakan sampel petugas kepolisian di Malaysia membuktikan bahwa norma subyektif memiliki pengaruh secara positif terhadap niat untuk melakukan whistleblowing internal, namun norma suyektif tidak berpengaruh terhadap minat untuk melakukan whistleblowing eksternal. Ponnu, dkk (2008) menemukan bahwa norma subyektif tidak berhubungan dengan minat whistleblowing internal. Begitu pula dengan hasil penelitian yang dilakukan oleh Poespito (2017) serta Rustiarini dan Sunarsih (2017) menemukan bahwa norma subyektif tidak mempengaruhi minat untuk melakukan whistleblowing. Zakaria, dkk (2016) yang meneliti minat petugas kepolisian di Malaysia berargumen bahwa penemuannya itu disebabkan oleh kebudayaan yang ada di Malaysia, yaitu nilai - nilai budaya Malaysia tidak mendorong pengungkapan urusan dalam negeri kepada pihak luar atau di luar institusi. Setiap masalah rahasia apapun harus diselesaikan secara internal. Ponnu, dkk (2008) yang meneliti minat dari eksekutif perbankan di Malaysia berargumen bahwa penemuannya itu disebabkan oleh obyek penelitiannya, yaitu sektor industri perbankan yang merupakan sektor yang sangat diatur sehingga kondisi ini berdampak pada pilihan mereka untuk melakukan whistleblowing. Rustiarini dan Sunarsih (2017) yang meneliti minat untuk melakukan whistleblowing dari auditor pemerintah di Bali mengungkapkan bahwa adanya tuntutan dari profesi akuntan agar semua auditor, termasuk auditor pemerintah, untuk bertindak independen dalam hal keputusan etis. Berdasarkan pada uraian tersebut, maka peneliti menyusun hipotesis alternatif sebagai berikut: $\mathrm{H} 2$ : Norma subyektif berpengaruh positif terhadap whistleblowing intention.

\section{Metode Penelitian}

\subsection{Populasi dan Teknik Sampling}

Populasi pada penelitian ini merupakan seluruh pengelola keuangan institusi sekolah yang meliputi kepala sekolah, wakil kepala sekolah, kepala tata usaha (TU), bendahara sekolah, dan administrasi keuangan di Sekolah Menengah Atas (SMA) Negeri, Madrasah Aliyah (MA), dan Sekolah Menengah Kejuruan (SMK) Negeri di Kota Malang sebanyak 214 orang. Teknik sampling menggunakan sampling jenuh. Sampling jenuh memiliki arti teknik penentuan sampel jika keseluruhan anggota populasi dipakai sebagai sampel (Sugiyono, 2017:126). 


\subsection{Jenis Penelitian dan Sumber Data}

Penelitian ini merupakan penelitian kausal (causal study). Penelitian kausal adalah penelitian yang menerangkan ada atau tidak adanya pengaruh antara variabel bebas (independen) terhadap variabel terikat (dependen) (Sekaran, 2013:98). Sumber data pada penelitian ini merupakan data primer. Data primer diartikan sebagai informasi yang diperoleh dari tangan pertama oleh peneliti (Sekaran, 2013:113).

\subsection{Variabel Penelitian}

Dalam penelitian ini dua jenis variabel, yaitu variabel bebas (independen) dan variabel terikat (dependen). Penelitian ini menjelaskan pengaruh variabel independen yaitu sikap dan norma subyektif terhadap variabel terikat (dependen), yaitu whistleblowing intention. Pengukuran indikator variabel adalah menggunakan skala likert lima poin, yaitu sangat tidak setuju (STS), tidak setuju (TS), netral (N), setuju (S), dan sangat setuju (SS). Variabel independen yang pertama adalah sikap. Sikap memiliki arti sejauh mana individu atau seseorang mempunyai evaluasi maupun penilaian yang baik atau tidak baik terhadap suatu perilaku (Ajzen, 1991). Variabel independen yang kedua adalah norma subyekif. Norma subyektif adalah pengaruh sosial yang berupa kepercayaan - kepercayaan orang lain yang akan mempengaruhi seseorang untuk melakukan atau tidak melakukan suatu perilaku (Ajzen, 1991). Variabel dependen pada penelitian ini adalah intensi whistleblowing (whistleblowing intention). Intensi atau minat didefinisikan sebagai keinginan untuk melakukan perilaku sedangkan perilaku adalah tindakan nyata yang dilakukan (Jogiyanto, 2007:29). Whistleblowing dapat diartikan sebagai pengungkapan kecurangan yang dilakukan oleh anggota organisasi kepada pihak yang dapat mengambil tindakan korektif atas pelanggaran tersebut.

\subsection{Uji Instrumen Penelitian}

\subsubsection{Uji Reliabilitas}

Reliabilitas sebenarnya merupakan alat untuk menguji kuesioner atau instrumen yang merupakan indikator variabel atau konstruk. Suatu instrumen kuesioner disebut reliabel apabila jawaban seseorang terhadap pernyataan konsisten (stabil) dari waktu ke waktu (Ghozali, 2016:47). Konstruk atau variabel yang dikatakan reliabel yaitu apabila menghasilkan nilai Cronbach Alpha > 0,70 (Ghozali, 2016:47).

\subsubsection{Uji Validitas}

Uji validitas adalah untuk mengukur sah atau valid tidaknya suatu instrumen kuesioner. Suatu kuesioner yang valid adalah apabila pertanyaan pada kuesioner memiliki kemampuan untuk mengungkapkan sesuatu yang akan diukur oleh kuesioner tersebut (Ghozali, 2016:52). Alat uji yang dipakai untuk mengukur tingkat interkorelasi antar variabel dan dapat atau tidaknya untuk dilakukan analisis faktor Kaiser - Meyer - Olkin Measure of Sampling Adequacy (KMO MSA). Angka yang dikehendaki harus $>0,50$ agar dapat dilakukannya analisis faktor (Ghozali, 2016:58).

\subsection{Metode Analisis Data}

Alat statistik pada riset ini adalah regresi linier berganda (Multiple linier regresion). Alat ini digunakan untuk mengetahui hubungan antara variabel bebas (independen) dengan variabel terikat (dependen), dan jumlah variabel independen yang digunakan adalah dua. Peneliti melakukan analisis statistik dengan bantuan software statistik SPSS versi 24. Model umum persamaan regresi yang dapat dibentuk adalah sebagai berikut:

$$
\mathrm{Y}=\alpha+\beta 1 \mathrm{X} 1+\beta 2 \mathrm{X} 2+\varepsilon
$$

Keterangan:

$\begin{array}{ll}\mathrm{Y}= & \text { Whistleblowing Intention } \\ \alpha= & \text { Konstanta } \\ \mathrm{X} 1= & \text { Sikap } \\ \mathrm{X} 2= & \text { Norma Subyektif } \\ \varepsilon= & \text { Eror }\end{array}$

\subsection{Uji Asumsi Klasik}

Uji asumsi klasik dalam penelitian ini terdiri dari 3 (tiga) jenis, yaitu uji multikolonieritas, heteroskedastisitas, dan normalitas. Uji multikolonieritas memiliki tujuan untuk menguji apakah pada model regresi terdapat korelasi antar variabel bebas (independen). Model regresi yang baik adalah seharusnya tidak terjadi korelasi di antara variabel bebas (independen) (Ghozali, 2016:103). Nilai cutoff yang umum dipakai untuk memperlihatkan terjadinya multikolonieritas adalah nilai Tolerance $\leq$ 0,10 atau sama dengan nilai VIF $\geq 10$ (Ghozali, 2016:134). Uji heteroskedastisitas memiliki tujuan untuk menguji apakah pada model regresi terjadi ketidaksamaan variance residual antara pengamatan yang satu dengan pengamatan yang lainnya. Dasar untuk melakukan analisisnya adalah apabila ditemukan pola tertentu, seperti titik - titik yang membentuk pola tertentu secara teratur (bergelombang, melebar kemudian menyempit), maka menunjukkan terdapatnya heeroskedastisitas. Jika tidak ditemukannya pola yang jelas dan titik - titik kelihatan tersebar di atas serta di bawah nilai 0 pada sumbu $\mathrm{Y}$, maka tidak ditemukannya heteroskedastisitas (Ghozali, 2016:134). Uji normalitas memiliki tujuan untuk menguji apakah pada model regresi, variabel pengganggu atau residual terdistribusi 
secara normal (Ghozali, 2016:154). Apabila terlihat data menyebar di area garis diagonal serta mengikuti arah dari garis diagonal, maka model regresi tersebut telah mencapai asumsi normalitas (Ghozali, 2016:156).

\section{Hasil Penelitian dan Pembahasan}

\subsection{Hasil Penelitian}

\subsubsection{Distribusi dan Pengembalian Kuesioner}

Sebanyak 214 kuesioner disebar kepada responden di 25 sekolah pada bulan April 2018 sampai dengan bulan Mei 2018. Distribusi dan pengembalian kuesioner ditampilkan pada Tabel 1.

Tabel 1 Distribusi \& Pengambilan Kuisioner

\begin{tabular}{|c|l|l|}
\hline No & \multicolumn{1}{|c|}{ Proses } & \multicolumn{1}{|c|}{ Jumlah } \\
\hline 1. & Kuesioner yang disebarkan & 214 eksemplar \\
\hline 2. & Kuesioner yang dikembalikan & 192 eksemplar \\
\hline 3. & $\begin{array}{l}\text { Kuesioner yang tidak diisi } \\
\text { lengkap }\end{array}$ & e eksemplar \\
\hline 4. & $\begin{array}{l}\text { Kuesioner yang digunakan untuk } \\
\text { penelitian }\end{array}$ & 192 eksemplar \\
\hline 5. & $\begin{array}{l}\text { Persentase pengembalian (respon } \\
\text { rate) }\end{array}$ & $89,72 \%$ \\
\hline 6. & $\begin{array}{l}\text { Persentase pengembalian yang } \\
\text { dapat digunakan untuk penelitian }\end{array}$ & $89,72 \%$ \\
\hline
\end{tabular}

Sumber: Hasil analisis, 2018

\subsubsection{Uji Regresi Berganda}

Hasil analisis regresi linier berganda ditampilkan pada Tabel 2 dibawah ini:

Tabel 2 Uji Regresi Berganda

\begin{tabular}{|c|c|c|c|c|c|c|}
\hline \multicolumn{7}{|c|}{ Coefficients $^{\mathrm{a}}$} \\
\hline & & \multicolumn{2}{|c|}{$\begin{array}{c}\text { Unstandardized } \\
\text { Coefficients }\end{array}$} & \multirow[t]{2}{*}{$\begin{array}{c}\text { Standardized } \\
\text { Coefficients }\end{array}$} & \multirow[b]{2}{*}{$\mathrm{t}$} & \multirow[b]{2}{*}{ Sig. } \\
\hline \multicolumn{2}{|c|}{ Model } & $\mathrm{B}$ & $\begin{array}{l}\text { Std. } \\
\text { Error }\end{array}$ & & & \\
\hline \multirow[t]{3}{*}{1} & (Constant) & 8.148 & 3.813 & & 2.137 & .034 \\
\hline & $\mathrm{S}$ & .382 & .096 & .287 & 3.981 & .000 \\
\hline & NS & .564 & .091 & .449 & 6.224 & .000 \\
\hline
\end{tabular}

a. Dependent Variable: WI

Sumber: Hasil analisis, 2018

Hipotesis satu menyatakan bahwa sikap (S) berpengaruh positif terhadap whistleblowing intention. Hipotesis tersebut dapat didukung jika koefisiennya bernilai positif dengan nilai signifikansi di bawah $5 \%$. Pada Tabel 2 menunjukkan bahwa signifikansi memiliki nilai 0,000 yang lebih rendah dari $5 \%$ dan koefisien yang bernilai positif. Oleh karena itu, data mendukung hipotesis satu.

Hipotesis dua menyatakan bahwa tingkat norma subyektif (NS) berpengaruh positif terhadap whistleblowing intention. Hipotesis tersebut dapat didukung jika koefisiennya bernilai positif dengan nilai signifikansi di bawah 5\%. Pada Tabel 2 menunjukkan bahwa nilai signifikansi sebesar 0,000 yang lebih rendah dari $5 \%$ dan koefisien yang bernilai positif. Oleh karena itu, data mendukung hipotesis dua. Adapun Koefisien determinasi ditampilkan pada Tabel 3, yaitu sebagai berikut:

\section{Tabel 3 Koefisien Determinasi}

\begin{tabular}{|c|c|c|c|c|}
\hline \multicolumn{5}{|c|}{ Model Summary } \\
\hline Model & $\mathrm{R}$ & R Square & $\begin{array}{c}\text { Adjusted R } \\
\text { Square } \\
\end{array}$ & $\begin{array}{l}\text { Std. Error of } \\
\text { the Estimate }\end{array}$ \\
\hline 1 & $.675^{\mathrm{a}}$ & .455 & .450 & 6.76693 \\
\hline
\end{tabular}

a. Predictors: (Constant), NS, S

Sumber: Hasil analisis, 2018

Dari tampilan output SPSS model summary, adjusted $\mathrm{R} 2$ bernilai sebesar 0,450, hal ini berarti $45 \%$ variasi whistleblowing intention dapat dijelaskan oleh variasi dari kedua variabel bebas (independen) yaitu sikap dan norma subyektif. Sisanya $(100 \%-45 \%=$ 55\%) dijelaskan oleh sebab lain di luar model.

\subsubsection{Uji Asumsi Klasik}

\section{a) Uji Multikolonieritas}

Uji multikolonieritas ditampilkan pada Tabel 4. Hasil uji multikolonieritas menunjukkan bahwa tidak ada multikolonieritas dalam model regresi.

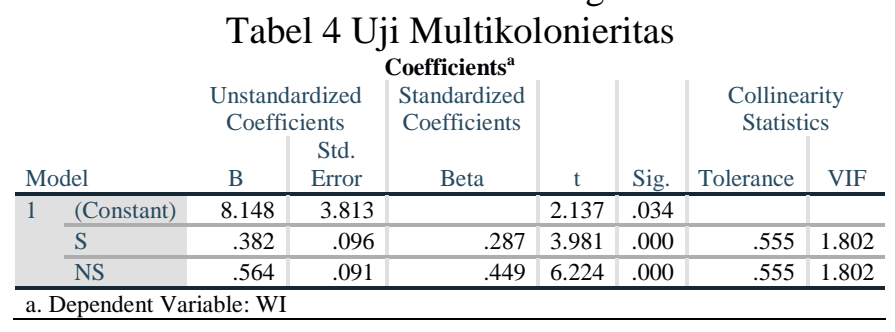

Sumber: Hasil analisis, 2018

b) Uji Heteroskedastisitas

Uji heteroskedastisitas ditampilkan pada gambar 2 . Hasil uji heterosekdastisitas menunjukkan bahwa tidak terdapat heteroskedastisitas dalam model regresi.

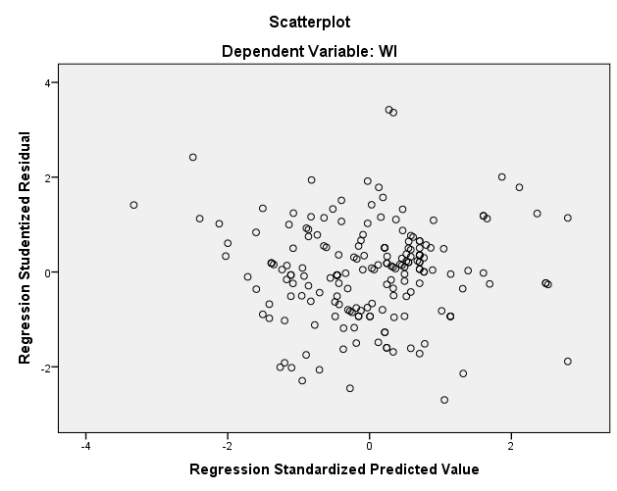

Gambar 2 Uji Heteroskedastisitas Sumber: Hasil analisis, 2018 
c) Uji Normalitas

Uji normalitas ditampilkan pada Gambar 3. Gambar 3 menunjukkan bahwa unsur normalitas sudah terpenuhi.

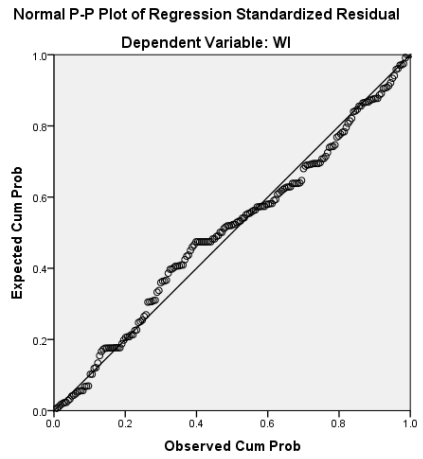

Gambar 3 Uji Normalitas

Sumber: Hasil analisis, 2018

\subsection{Pembahasan}

\subsubsection{Pengaruh Sikap terhadap Whistleblowing Intention}

Sikap terhadap perilaku (attitude toward behavior) adalah salah satu konstruk dalam teori tindakan beralasan (Theory of Reasoned Action - TRA) yang dikemukakan oleh Ajzen dan Fishbein diTahun 1980. Sikap (attitude) memiliki arti perasaan positif atau negatif yang ada pada diri individu atau seseorang untuk melaksanakan suatu tindakan nyata (Jogiyanto, 2007:35). Dalam TRA, sikap akan mempengaruhi keinginan seseorang atau individu untuk mewujudkan suatu bentuk perilaku. Semakin berpersepsi positif seseorang terhadap suatu perilaku, maka keinginan orang tersebut untuk melakukan perilaku tersebut juga akan bertambah tinggi. Penelitian ini sesuai dengan yang dinyatakan dalam TRA bahwa sikap berpengaruh positif terhadap minat untuk melakukan tindakan whistleblowing.

Whistleblowing yang merupakan tindakan mengungkap/ melaporkan kecurangan/ pelanggaran kepada pihak yang yang memiliki kemampuan untuk mengambil action atas kecurangan atau pelanggaran adalah perilaku yang positif. Responden beranggapan bahwa whistleblowing merupakan suatu tindakan yang penting untuk mencegah kerugian yang diakibatkan oleh tindakan fraud. Sesuai dengan pernyataan Mustapha dan Ling Ling (2012), bahwa whistleblowing diklaim sebagai alat yang penting untuk mengurangi korupsi dan situasi yang berbahaya karena whistleblowing dapat meningkatkan pengungkapan informasi tentang kegiatan ilegal, berbahaya, atau tidak etis oleh pemerintah dan organisasi swasta. Kondisi ini menunjukkan bahwa whistleblowing merupakan suatu alat yang dianggap penting untuk mencegah terjadinya pelanggaran dalam pengelolaan keuangan yang dapat mengakibatkan kerugian dalam institusi pendidikan.

\subsubsection{Pengaruh Norma Subyektif terhadap Whistleblowing Intention}

Norma subyektif (subjective norm) merupakan konstruk lainnya yang terdapat dalam teori tindakan beralasan (Theory of Reasoned Action - TRA). Norma subyektif adalah pengaruh sosial yang akan dapat mempengaruhi seseorang mewujudkan atau tidak mewujudkan suatu bentuk perilaku. Semakin tinggi pengaruh sosial yang diterima seseorang untuk melakukan suatu perilaku, maka berdampak pada semakin tinggi pula minat orang tersebut untuk mewujudkan perilaku tersebut.

Sesuai dengan TRA, hasil riset ini membuktikan bahwa norma subyektif berpengaruh secara positif terhadap whistleblowing intention. Hal ini menunjukkan bahwa niat seseorang untuk melakukan tindakan whistleblowing dapat dibangun melalui lingkungan sosial mereka. Semakin besar dukungan dari lingkungan sosial mereka yang antara lain rekan kerja, atasan, teman, dan keluarga akan dapat berpengaruh terhadap besarnya niat mereka untuk melakukan tindakan whistleblowing. TRA juga berlaku dalam pengelolaan keuangan dalam institusi pendidikan. Kebijakan whistleblowing akan lebih efektif apabila didukung juga oleh lingkungan sosialnya.

\section{Kesimpulan}

Dalam institusi pendidikan, minat individual untuk melakukan tindakan whistleblowing dapat diprediksi melalui teori tindakan beralasan (Theory of Reasoned Action - TRA). Konstruk TRA, yaitu sikap dan norma subyektif terbukti berpengaruh secara positif terhadap minat untuk melakukan tindakan whistleblowing. TRA dapat dijadikan sebagai acuan oleh penyusun kebijakan whistleblowing dalam menyusun serta meningkatkan efektivitas kebijakan dan sistem whistleblowing pada institusi pendidikan. Berdasarkan TRA, efektivitas sistem dan kebijakan whistleblowing pada instiusi pendidikan dapat dipengaruhi oleh pandangan positif atau negatif dari pegawai yang bersangkutan maupun pengaruh dari lingkungan sosial pegawai tersebut. Oleh karena itu, penyusun kebijakan whistleblowing perlu melakukan sosialisasi kepada pegawai pada institusi pendidikan maupun kepada masyarakat secara luas mengenai manfaat sistem dan kebijakan whistleblowing yaitu untuk menekan potensi fraud yang dapat menimbulkan kerugian pada institusi pendidikan. 


\section{Daftar Pustaka}

Ajzen, Icek. (1991). The Theory of Planned Behavior. Organizational Behavior and Human Process, Vol. 50, pp.179- 211.

Aliyah, Siti. (2015). Analisis Faktor - Faktor yang Mempengaruhi Minat Pegawai dalam Melakukan Tindakan Whistle - Blowing. Jurnal Dinamika Ekonomi \& Bisnis, Vol. 12 No. 2 (Oktober 2015), pp. 173 - 189.

Antara, Agregasi. (2017). Mantap! Pendidikan AntiKorupsi Dimasukkan di Sekolah. Okenews [Internet], 4 Agustus 2017. Dapat diakses pada https://news.okezone.com/read/2017/08/04/65/17 49710/mantap-pendidikan-anti-korupsidimasukkan-di-sekolah [Diakses pada 13 Maret 2018.

Bagustianto, Rizki dan Nurkholis. (2014). Faktor Faktor yang Mempengaruhi Minat Pegawai Negeri Sipil (PNS) untuk Melakukan Tindakan Whistle - Blowing (Studi pada PNS BPK RI). Jurnal Ilmiah Mahasiswa FEB Universitas Brawijaya. Vol. 3, No. 1, pp. $1-18$.

Crook, David. (2000). How to Encourage Whistleblowing. Journal of Financial Regulation and Compliance. Volume 8, Number 4, pp.326332.

Ghozali, Imam. (2016). Aplikasi Analisis Multivariate dengan Program IBM SPSS 23. Badan Penerbit Universitas Diponegoro, Semarang.

Handayani, Titik. (2009). Korupsi dan Pembangunan Pendidikan di Indonesia. Jurnal Kependudukan Indonesia, Vol. IV, No. 2, pp. 15 - 34.

Jogiyanto HM. (2007). Sistem Informasi Keperilakuan. Andi, Yogyakarta.

Khairunnisa, Rifdah Yuri. (2017). Faktor - Faktor yang Berpengaruh terhadap Intensi Whistleblowing (Studi Kasus pada Satuan Pengawas Internal Perguruan Tinggi Negeri di Kota Malang), Skripsi, Jurusan Akuntansi, Fakultas Ekonomi dan Bisnis Universitas Brawijaya.

Lembaga Pengembangan dan Pemberdayaan Kepala Sekolah Kementerian Pendidikan dan Kebudayaan Indonesia. (2013). Bahan Pembelajaran Diklat Calon Kepala Sekolah Pengelolaan Keuangan Sekolah/ Madrasah. Karanganyar: Lembaga Pengembangan dan Pemberdayaan Kepala Sekolah Kementerian Pendidikan dan Kebudayaan Indonesia.

Mulyasa, E. (2009). Manajemen Berbasis Sekolah, Konsep, Strategi, dan Implementasi. Remaja Rosdakarya, Bandung.

Mustapha, Mazlina \& Siaw Ling Ling. (2012). Whistle Blowing: Perceptions of Future Accountants.
2012 International Conference on Economics, Business Innovation IPEDR Vol. 38. IACSIT Press, Singapore.

Parianti, Ni Putu Ika, I Wayan Suartana, dan I Dewa Nyoman Badera. (2016). Faktor - Faktor yang Memengaruhi Niat dan Perilaku Whistleblowing Mahasiswa Akuntansi. E - Jurnal Ekonomi dan Bisnis Universitas Udayana, Vol. 5(12), pp. 4209-4236.

Park, H. dan J. Blenkinsopp. (2009). Whistleblowing as Planned Behavior - A Survey of South Korean Police Officers. Journal of Business Ethics, Vol. 85(4), pp.545-556.

Poespito, Alfian Setyo. (2017). Determinan Minat Pegawai dalam Melakukan Tindakan Whistleblowing, Skripsi, Jurusan Akuntansi, Fakultas Ekonomi dan Bisnis Universitas Brawijaya.

Ponnu, C.H., K. Naidu, dan W. Zamri. (2008). Determinants of Whistle Blowing. International Review of Business Research Papers, Vol. 4, No. 1 (January), pp.276-298.

Ramadhan, Aditya. (2016). Lapor Kecurangan Sekolah ke Satgas Antimafia Pendidikan. Antaranews [Internet], 28 Januari 2016. Dapat diakses pada https://www.antaranews.com/berita/570422/laporkecurangan-sekolah-ke-satgas-antimafiapendidikan [Diakses pada 16 Januari 2016].

Rustiarini, Ni Wayan dan Ni Made Sunarsih. (2017). Factors Influencing the Whistleblowing Behaviour: A Perspective from the Theory of Planned Behaviour. Asian Journal of Business and Accounting, Vol. 10(2), pp.187-214.

Sekaran, Uma., \& Roger Bougie. (2013). Research Methods for Business. John Wiley \& Sons, Inc, USA.

Sharif, Zakiyah. (2015). Intention Towards Whistle Blowing Among Internal Auditors in the U.K. Disertasi, Business School, Universitas Huddersfield.

Siallagan, Hamonangan, Abdul Rohman, Indira Januarti, Muhammad Din. (2017). The Effect of Professional Commitment, Attitude, Subjective Norm and Perceived Behavior Control on Whistle Blowing Intention. International Journal of Civil Engineering and Technology, Volume 8, Issue 8 (August), pp.508-519.

Sugiyono. (2017). Metode Penelitian Kuantitatif, Kualitatif dan Kombinasi (Mixed Methods). Alfabeta, Bandung.

Suryono, Erwan dan Anis Chariri. (2016). Sikap, Norma Subjektif, dan Intensi Pegawai Negeri Sipil untuk Mengadukan Pelanggaran (Whistle-Blowing). 
Jurnal Akuntansi dan Keuangan Indonesia, Volume 13, Nomor 1 (Juni), pp.102-116.

Susanti, Apriliya. (2018). Mencegah Korupsi di Sekolah. Koran Jakarta [Internet], 11 Januari 2018. Dapat diakses pada http://www.koranjakarta.com/mencegah-korupsi-di-sekolah/ [Diakses pada 16 Januari 2016].

Transparency International. (2016). Corruption Perceptions Index 2016. Dapat diakses pada https://www.transparency.org/news/feature/corrup tion_perceptions_index_2016 [Diakses 11 Oktober 2017].

Waytz, Adam, James Dungan., \& Liane Young. (2013). The Whistleblower's Dilemma and the Fairness Loyalty Tradeoff. Journal of Experimental Social Psychology. Vol. 49, pp.1027-1033.

Wei, Liang - Cheng, Carol Hsu., \& Kai Wang. (2016). Intentions of Employees to Whistleblow Information Security Policy Violations in the Organization. Asia Pacific Journal of Information Systems, Vol. 26 No. 1, pp.163-188.

Winardi, Rijadh Djatu. (2013). The Influence of Individual and Situational Factors on LowerLevel Civil Servants' Whistle-Blowing Intention in Indonesia. Journal of Indonesian Economy and Business, Volume 28, Number 3, pp.361-376.

Windarti. (2015). Pengaruh Karakteristik Pengelola Keuangan Sekolah dan Transparansi terhadap Efektivitas Pengelolaan Keuangan pada SMA dan SMK Negeri di Kota Madiun. ASSETS: Jurnal Akuntansi dan Pendidikan, Vol. 4, No. 1, (April), pp.23-36.

Zakaria, Maheran, Siti Noor Azmawaty Abd Razak, dan Muhammad Saiful Anuar Yusoff. (2016). The Theory of Planned Behaviour as a Framework for Whistle - Blowing Intentions. Review of European Studies, Vol. 8, No. 3, pp.221-236.

Zakaria, Maheran. (2015). Antecedent Factors of Whistleblowing in Organizations. 7th International Conference on Financial Criminology 2015, 13 - 14 April 2015, Wadham College, Oxford, United Kingdom. 